\title{
Vladimir Mayakovsky as Exemplary Character: Two Interpretations by Dario Fo and Carmelo Bene
}

\section{Malcolm Angelucci and Stephen Kolsky}

Abstract: This article contributes to the mapping of the role played by the Russian poet, playwright, artist and performer Vladimir Mayakovsky (1893-1930) in the Italian context of the 60s and 70s, concentrating on Dario Fo's L'operaio conosce 300 parole, il padrone 1000, per questo lui è il padrone (1969), and Carmelo Bene's TV production of Bene! Quattro modi di morire in versi (1974, broadcast in 1978). Mayakovsky appears here as a character, constructed as an exemplary figure for the role of the artist. After framing exemplarity theoretically as a strategy that effaces the intrinsic discrepancy between example and rule, the article will map the presence of this rhetorical move in the two texts. It will discuss the ways in which they share a series of common features, forming in both cases an implicit agenda of legitimization at a time when both Fo and Bene were shifting the context of their practice. In this sense, this contribution argues that Fo's L'operaio and Bene's Quattro modi both introduce a programmatic element that defines a specific poetic and politics, and at the same time attempt at performing the very poetic that is being presented.

This article contributes to the mapping of the role played by the Russian poet, playwright, artist and performer Vladimir Mayakovsky (1893-1930) in the Italian context of the $60 \mathrm{~s}$ and $70 \mathrm{~s}$, concentrating on the following two theatrical performances: Dario Fo's L'operaio conosce 300 parole, il padrone 1000, per questo lui è il padrone (1969), and Carmelo Bene's TV production of Bene! Quattro diversi modi di morire in versi (1974, broadcast in 1978). Mayakovsky appears here as a character, constructed as an exemplary figure for the role of the artist. We will discuss how these two constructions share a series of common features, forming in both cases an implicit agenda of legitimization at a time when both Fo and Bene were shifting the context of their practice: the introduction of a 
programmatic element that defines a poetic and politics; an attempt at performing the very poetic that is being presented.

What is at stake here is a definition of exemplarity and the role it performs in the texts. The notion of a logical straightforward relationship between example and rule, the particular and the general, has been challenged by the so-called post-structuralist turn. The elaboration of Jacques Derrida's and Paul De Man's thinking on exemplarity by scholars such as Alexander Gelley and Irene Harvey argues for the need to bring to light a necessary element of failure in the logic of exemplarity: a failure through which, paradoxically, its inductive/deductive function can be fulfilled. This means reading the texts against the grain-against what they explicitly set out to do-showing how an element of betrayal is necessary for the agenda of the two texts to be both articulated and performed. A famous quotation from De Man neatly summarises the issue:

But can any example ever truly fit a general proposition? Is not its particularity, to which it owes the illusion of its intelligibility, necessarily a betrayal of the general truth it is supposed to support and convey? (276)

Thus the gesture of the example towards the rule necessarily—logically—misses its target. Hence, instead of being deployed as a logical tool, it is used rhetorically, in order to convince and persuade of the validity of an argument.

This rhetorical turn in the understanding of exemplarity requires a rethinking of the relationship between particular and general. Gelley sees this as the necessity to think this relationship as working in both directions. Exemplarity does not work as pure induction, from the particular to the universal, but any specific example is chosen and constructed from a preconceived idea of the general rule it is called to help deriving. In other words, an agenda is intrinsically at play in this rhetorical construction, and it is what makes it work, what makes it persuasive.

Harvey is the scholar who puts this theoretical point at the centre of her approach to critical reading of exemplarity. In her work on Rousseau's Emile, the mapping of the occurrences of exemplarity brings to light what she defines as hidden "economies" at play in the text. In her view, the relation between an example and the teaching of a rule functions because of a concurrent series of implicit, unspoken or hidden mechanisms that make exemplarity possible. In Emile, Harvey identifies idealisation (in the form of the construction of the example as the ego 
ideal for the pupil) (29), dramatisation, mimesis and fiction (24) as the main strategies at play. Some of Harvey's categories clearly fit with our case studies. The fact that Mayakovsky is presented as a character in a theatrical production, for example, immediately calls for a reading of its fictional stylisation and reenactment. ${ }^{1}$ However, it is important to stress from the outset that Harvey's aim is not to provide a new generalisation about exemplarity, a new definition in which her economies are essentialised as fixed interpretive categories. Her call instead is for a close reading of each new text, as a laying bare of its particular persuasive strategies embedded in exemplarity and, with them, its underlying ideology.

During the 60s and 70s two rather different Mayakovskys inhabit the Italian scene. Each of them, we will argue, embodies and performs a perlocutionary role that fits with an idea of exemplarity as "persuading, convincing, frightening, making someone act in a certain way" (Suleiman 26). In one manifestation, Mayakovsky is a "Marxist" guiding the masses towards revolution in a casa del popolo, while in the other he is practicing and professing his "anarchism" ${ }^{\text {on }}$ public television. We will argue, however, that these characters and these texts, despite their different poetic and political aims, share a common economy. We will call this economy a 'manifesto', as it shares some important features with the genre. According to Luca Somigli, "the purpose of the manifesto [...] is to oppose a certain dominant discourse with a counter-discourse designated to replace it, and to shift the power to define the subject to the subject himself" (32). In this, it has a "suasive function" (34), as it "interpellates its addressee and constitutes him or her as the subject of a new ideological discourse, and it simultaneously defines its issuer as the spokesperson of the new authority upon which this counterdiscourse finds its validity" (38). We will argue that, for both artists, Mayakovsky is instrumental in putting forward an agenda of self-legitimisation and self-establishment in the wider theatrical scene of their time. Fo and Bene's success in this regard, their success at "persuading," comes however at the price of a contradiction with the poetics and politics that they have explicitly set out to perform. Fo's L'operaio presents us with a militant manifesto that performs and teaches the role of the

\footnotetext{
${ }^{1}$ Our two texts diverge in this sense: in Quattro modi Bene plays Mayakovsky (as well as the other three poets) whereas in L'operaio Fo does not appear on stage at all. Nevertheless his presence, his voice through the writing process, and more generally the entire concept of his play as a political act, enter into a complex dialogue with the example of (his) Mayakovsky.

${ }^{2}$ We use the term 'anarchism' as an introductory and preliminary definition of Bene's poetics. A further defense of this term will be provided in the course of our discussion.
} 
artist as a revolutionary, hiding a nostalgia for the artist as the voice of the party. Bene's Quattro modi, a belligerently anti-pedagogical text, finds its strength and coherence only through the presentation and defence of specific poetic and aesthetic categories.

In order to demonstrate our hypothesis, we will proceed as follows. Firstly we will provide an introduction to L'operaio and Quattro modi in the context of each artist's respective career. Following this, we will separately unpack the strategies of exemplarity in each text, to finally present an unexpected similarity in structure, in two works and artists that could not otherwise be more dissimilar.

\section{Fo's L'operaio and Mayakovsky}

L'operaio is situated in the period of the 1968 student movement and the autunno caldo of 1969 (Mitchell 89-91). First performed in November 1969, it is the expression, or manifesto, of Fo's concept of theatre as revolutionary-didactic. This concept of theatre as a practical tool for revolutionary change represents a shift or break (datable to October 1968) from his previous, albeit radical, productions that until then had been performed within the boundaries of the bourgeois theatre circuit. On the poster for L'operaio he declared: "intendiamo porci al servizio della causa rivoluzionaria" (Colombo and Piraccini 110). According to Franca Rame, his wife and collaborator, they had made the decision to no longer act as the "giullari della borghesia" but to become instead the "giullari degli sfruttati" through the formation of a new company Nuova Scena (Fo, Le Commedie VIIVIII; Farrell 108-11). As a consequence, Fo needed to convince the public of his revolutionary credentials, and he self-consciously attempts to do this through a lecture or lesson: the performance of the play itself. The title unambiguously sets out his statement of intent in the form of a political slogan: the oppression of the workers is the result of linguistic domination, extending to the cultural domain, and is the principal means by which bourgeois hegemony is maintained. Fo claims that the title is a textual borrowing from Lettera a una professoressa written by the pupils of the Scuola di Barbiana (Fo, Teatro politico 221). This is not true. ${ }^{3}$ The

${ }^{3}$ Lettera a una professoressa makes a pertinent comment about the scholastic use of Monti's translation of Homer: "E il Monti chi è? Uno che ha qualcosa da dirci? Uno che parla la lingua che occorre a noi?" (Scuola di Barbiana. Lettera a una professoressa 28). The "Scuola" has clear ideas about language which are shared by Fo: "Le lingue le creano i poveri e poi seguitano a rinnovarle all'infinito. I ricchi le cristallizzano per poter sfottere chi non parla come loro" 
extratextual reference to the Lettera is significant, perhaps even more so because it is false. Fo is seeking to authorize his own pedagogical project by linking it to the Scuola di Barbiana. In L'operaio he takes up the concept that school inculcates an oppressive interpretation of culture which needs to be replaced by a new conception: "la cultura vera [...] è fatta di due cose: appartenere alla massa e possedere la parola" (Scuola di Barbiana. Lettera a una professoressa 105; see also $115,133)$. He literally teaches the workers "a few words," doing so quite explicitly through the repetition of slogans; exposing them to revolutionary culture through the vehicle of examples.

Joseph Farrell calls Mayakovsky Fo’s “alter ego" (Farrell 118) insofar as Fo models himself on the proteiform production of the earlier artist, attributing to him his concept of the fundamental characteristics of a revolutionary writer: "io sono con lui" (Majakovskij, Messaggi ai posteri selezionati e condivisi da Dario Fo. 18). ${ }^{4}$ Mayakovsky had earlier stimulated Fo's theatrical practice by his use of pantomime, puppets and circus routines. The latter's almost contemporaneous Mistero buffo takes its title from the Russian author's Misteriya buff: it is possible that Fo recognized in it a revolutionary reworking of the medieval mystery play (D'Arcens 77-8) although he claims this was not the case. Over twenty years later, in 1994, he would also publish a selection of Mayakovsky's poetry with commentary, Messaggi ai posteri.

During the play a group of workers, in the role of audience, discuss amongst themselves what they see on stage. They also interrogate and interact with a number of exemplary characters represented in such a way as to clarify their precise pedagogical intent. This is not a one-way system, however: the workers' disagreements and discussions are focalized within the play in anticipation of the discussions of the so-called "third act" that follows the performance (although it can be considered an integral part of the ideological re-performance of the play, with the

(Scuola di Barbiana. Lettera a una professoressa 18-19; see also 96). The term "padrone" is used in the Lettera to indicate those capitalist forces that determine the shape of learning: "Spesso c'è venuto di parlare del padrone che vi manovra. Di qualcuno che ha tagliato la scuola su misura vostra" (Scuola di Barbiana. Lettera a una professoressa 71).

${ }^{4}$ Referring to two poems of 1915, Fo states "c'è da farsi delle belle risate. E non perché, coi tempi che stiamo vivendo noi in italia, ci sembrano raccontare perfettamente la nostra società.... Majakovskij sarebbe un cantore magnifico dei nostri giorni" (Majakovskij 46 our emphasis; see also 148). This suggests a strong continuity in Fo's work in regard to the Russian artist and mirrors his exemplary function in L'operaio. 
involvement of the actors and sometimes Dario Fo). In so doing, they model the reception of the play and, in this sense, they are exemplary of the implied audience of workers. This becomes especially apparent at the end when the workers decide to reinstate the library that they have been dismantling, having become convinced of the importance of culture in any revolutionary movement.

The play proceeds by the introduction of a succession of exemplary figures, the majority of whom have troubled relations with the Communist Party. The exceptions are Gramsci (founder of the Partito Communista Italiano) and Michele lu Lanzone (a Sicilian trade unionist who was murdered by the Mafia while pursuing peasant land rights in the 1950s). The playlet about Michele lu Lanzone is Fo's declared/signed contribution to the plays-within-the-play where significantly the Party does not have a role. In the first act, two of the characters, Borna Kvanic and Rudolf Slansky (the latter the victim of a notorious show trial in Czechoslovakia in 1952), are tortured and humiliated. Both admit to falsehoods about their behaviour in order to emphasize the ruthlessness of the Communist Party in Eastern Europe and the dangers of disconnecting oneself from the proletariat. The second act concentrates on the role of the intellectual and writer in revolutionary politics but this time, unlike in the first act, the exemplary figures are regarded as positive models. Gramsci in conversation with the workers is a model of the organic intellectual. He is followed by the single contemporary example, the dramatist Fo himself (not through his own character but through his text Michele lu Lanzone performed by Franca Rame). The final episode, which is centred on the Soviet poet and playwright Mayakovsky, concludes with a performance of the unity of the workers through a reading from his epic poem on the death of Lenin.

\section{Bene's Quattro modi and Mayakovsky}

Bene's production of his Mayakovsky for Italian public television is, like Fo's L'operaio, an early attempt to engage with a new context and a new audience. Following his avant-garde period leading to the season of the underground cantine romane, and after the clamour of the polemics surrounding his participation to the Venice film festival of 1969 and subsequent films, the 70s saw the enfant terrible consistently and successfully establish himself as a central figure in the Italian theatre scene (Giacchè 59; Petrini 28). Needless to say, this centrality is 
in need of political and aesthetic justification. ${ }^{5}$ The choice of Mayakovsky for Bene's debut in the far-reaching medium of television signals the importance of the Russian poet in Bene's oeuvre. This choice was and would become a recurrent trait in the first two decades of Bene's career. According to Piergiorgio Giacchès systematisation, between 1960 and 1980 there are eight productions featuring the poetry of Mayakovsky. The Spettacolo-concerto in 1960 initiates a series that lasts until the last 're-edition' of the concert for the Sagra Musicale Umbra in 1980, and the album for Fonit Cetra of the same year. Mayakovsky and his works are used both as means of legitimisation and a poetic laboratory. After his unsatisfactory debut in Camus' Caligula in 1959, Bene turns to Mayakovsky; he uses it again for his debut in the LP market in 1962, with the album for RCA, and, once again, more than ten years later, with the Quattro modi for RAI. In this production, Bene works at two interwoven levels. He provides a reading of the poetry of the four Russian poets Mayakovsky, Esenin, Blok and Pasternak, while playing them as characters. Amongst the four, Mayakovsky's exemplary role is programmatically signalled from the very beginning, in the title: the "Bene!" of Bene! Quattro diversi modi di morire in versi plays with the homophony between the actor's surname and the title of a well-known poem by Mayakovsky. From the beginning, the actor is merging with his "character" and, as we will discuss, this implies the merging of the two poetics, by means of embodiment of the latter by the former. Furthermore, the arrangement of the poems constructs Mayakovsky as the interpreter and judge of the other three authors, while at the same time projecting him (as poet and character) as the protagonist of the piece.

\section{The example of Mayakovsky in Fo's L'operaio}

Fo's portrayal of Mayakovsky in L'operaio brings to a climax his series of exemplary historical re-enactments with pointed relevance for contemporary politics. This final episode commences with a comic grotesque rendition of the Russian artist's suicide, moving through to a satirical discussion about his relationship with the Communist Party on cultural matters, and culminating with a choric recitation of his poem on the death of Lenin. Mayakovsky as character in L'operaio becomes the exemplar of revolutionary writing that validates Fo's own practice and aspirations, providing the exemplary precedent of a writer who is in conflict with

\footnotetext{
${ }^{5}$ Evidence of this ongoing necessity is Bene's positioning paper as director of the theatre section of Venice Biennale in 1989 (Bene, "La ricerca teatrale nella rappresentazione di stato")
} 
the communist party as arbiter of the literary field. Indeed, L'operaio defends and justifies Fo's poetics as well as performing them through Mayakovsky.

The play revolves around a group of workers in the process of dismantling the library of a casa del popolo, which is then selectively reconstructed as a revolutionary library-a self-referential selection that is performed as Fo's political and cultural manifesto. In order to comprehend the role of examples, we need to see the play as championing the revolutionary cause outside and against the contemporary Italian Communist Party (PCI), legitimizing the writer in this action, and theatrically demonstrating the theoretical basis for this operation. We can regard L'operaio as a manifesto insofar as it intends to "open up new spaces for oppositional praxis" and seeks to engage in "change-writing" (Ebert 553). According to Somigli, "writing manifestoes remains a privileged way for dissenting or marginalized voices to speak out, to affirm their presence [...] and invite them to band together for a common cause" (22). The action of the play foreshadows proletarian action outside its boundaries; it is literally an event. Inscribed within Fo's manifesto is the use of slogans and, most significantly, examples. Slogans function as calls to action, and as such at the end of the play they form a potent restatement of his ideological purpose (Fo, Le Commedie 128-29). They have moreover been described by Deleuze and Guattari as "order-words" (mots d'ordre) that can "reshape and reconstitute [the social-political world] in an expressly material way" (Deleuze and Guattari 91-2; Porter 234).

In L'operaio, both the manifesto as a genre and the slogan share some key features with the example: all have in common the desire to incite action beyond the text, a demand for a new vision of communism, and the clear articulation of a revolutionary theatre. Their perlocutionary effects are intended to be immediate and provocative. Directly associated with such a critique is the construct of the intellectual-writer who will not be subordinated to the Party but will create dynamic, exemplary resources for the workers by educating them in and through revolutionary culture. ${ }^{6}$ Narrative becomes embodied as dramatic discourse, taking the form of "living" knowledge ("conoscenza viva") (Fo, Teatro politico di Dario

\footnotetext{
${ }^{6}$ The success of the strategy is indicated by the following comments from a member of the audience after a performance: "Questo spettacolo ci ha entusiasmato, ci ha toccato fino in fondo e ci deve spingere a andare a casa a far politica, a leggere gli autori che sono stati citati dagli autori: Lenin, Gramsci, Mao; a cercare di capire, il più presto possibile, perché è urgente" (Fo, Teatro politico di Dario Fo. Compagni senza censura. Vol 1. 178). Notably absent from these comments are the literary figures of the play.
} 
Fo. Compagni senza censura. Vol 1. 104). The examples work together with slogans that encapsulate both Fo's political position and the workers' commentary within the play, presenting situations in an analogical relationship to the present that illuminate and "exhort" the role of culture in the revolutionary struggle. Indeed the actor-workers model the reception of the play, and in this sense are exemplary of the implied audience of workers. This becomes especially apparent when the chorus of workers decides to restore the library (destined for oblivion) that they had been packing up, having become convinced of the importance of culture in any revolutionary movement. The finale of the play, where audience and actors unite in reciting passages from Mayakovsky, is emblematic of the writer initially stimulating and subsequently becoming part of mass revolution. ${ }^{7}$

Each enactment of events or episodes is taken from the past but revisited and revised to create a continuity of significance for the present-a connection that is essential to establish the pedagogical and exemplary authority of the play (Puchner 25-6, 29). ${ }^{8}$ Fo is the teacher who employs exemplars working outwards from the particular to the general so that his version of history provides the authority and guidance to persuade the audience of his stance on revolutionary politics.

It will be useful at this point to reflect on Fo's deployment of examples through Kant's well-known analysis of them, starting from the philosopher's oftquoted statement that "examples are the leading-strings of the power of judgment, which he who lacks the natural talent of judgment can never do without" (Critique of Pure Reason. B174, 269). However such illumination comes at a cost

\footnotetext{
7 Many years after the event Fo stated that when the actors declaimed the poem during the performance they were accompanied by members of the audience: "a cui noi avevamo distribuito preventivamente il testo in modo che la solitaria declamazione si transformava in una grande voce collettiva. Devo dire anche con un bell'effetto finale" (Majakovskij, Messaggi ai posteri selezionati e condivisi da Dario Fo. 112). It is important to note that the singularity of the poet's voice produces the rhetorical result of the workers standing together, united through a shared cultural experience. The perlocutionary effect is therefore carefully stage-managed and performed.

${ }^{8}$ A discussion point amongst the workers of L'operaio is the relationship between history and the present: the importance of finding one's revolutionary roots guided by the dramatist (Fo, $\mathrm{Le}$ commedie di Dario Fo, Vol. 3 93-4). The example of Gramsci interacting with workers elicits the following comment from the "prima operaia": "Ma, guarda, e io che credevo che fosse una scena di adesso" (Fo, Le commedie di Dario Fo, Vol. 3 106) when in fact, it is pointed out that the scene took place in 1919. Thus the examples are read as having direct connections with the present struggle, training the workers to read examples competently (Suleiman 36,46).
} 
as "examples usually do it [the insight of the understanding] some damage" and moreover "often weaken the effort of the understanding to gain sufficient insight into rules in the universal" which become "more like formulas than like principles" (Critique of Pure Reason. B174, 269). These statements can be instructively applied to L'operaio where the intellectual Fo employs examples to teach the workers " 1000 parole" of the play's title so they gain parity with the "padrone" in accordance with Aristotle's view that the example has a rhetorical function, persuasive, "destined for a nonspecialist audience" (Lyons 10-11). The example of Mayakovsky is based on a traditional view of the "truly exemplary exemplar projected toward an ideal" (Lloyd 264)—the ideal here being the revolutionary goal of societal change. There is no indication that Fo sees this on a conscious level as in any way problematic but it does give rise to interpretative issues, as we shall later see.

The sequencing of the second act begins with Gramsci as 'tutor' to a group of workers, followed by the performance of Michele lu Lanzone, and culminating in the example of Mayakovsky. It operates with the precise goal of establishing a revolutionary poetics and program of action. If viewed from the perspective of the first act where the Stalinist Communist Party brutally imposes a single version of events - its own - and Slansky is accused of losing contact with the "base" (Fo, Le commedie di Dario Fo, Vol. 3 102), the second act programmatically proposes a reversal of this position through these three exemplary figures. Gramsci is in direct contact with the factory workers; Michele lu Lanzone organizes the peasants through direct action, and Mayakovsky performs the role of the poet singing an anthem to an authentic Communist Party after the death of Lenin.

Fo explains that Mayakovsky deliberately devised his poetic output so that it could reach "un più vasto pubblico possibile... per poter dire cose intelligenti a molte persone...Provocare, convincere, mettere a disagio, questo è stata la lezione di Majakovskij" (Majakovskij, Messaggi ai posteri selezionati e condivisi da Dario Fo. 22). Use of the term "lezione" would lead one to presuppose that the teacher in the last example is the Russian writer-but not only has Fo appropriated his messages for contemporary Italy, he has become the teacher himself. He has updated the ideological and cultural references in order to highlight his own emphases and engagement, adapting the lesson to his audience. If the theatrical space is the classroom and the play is the means of illumination and clarification, Kant's students are comparable to the workers who attend L'operaio. The playwright's examples should not lead to mere imitation but a going beyond (Lloyd 264-5). The example of Mayakovsky is made relevant to the needs of the workers through the 
"Pantomima di quello che avverrà" (Fo, Le Commedie di Dario Fo, Vol. 3 122-24) in which contemporary events such as, for example, Vietnam and Czechoslovakia, are satirically reviewed. Although performed in a style of which Mayakovsky would not have disapproved, and did indeed employ, the "Pantomima" also recalls Fo's own Grande pantomima (first performed in the autumn of 1968). In this way, Fo organizes the play so that this adaptation of Mayakovsky to contemporary exigencies emphasizes the role of the intellectual/writer as pedagogue of the working class.

To this end Fo foregrounds Mayakovsky's move to impromptu performance spaces in factories, just as he himself was doing. The crucial point is that there does not appear to be any record of Mayakovsky staging performances of his plays in factories in the way described by Anna (who herself seems to be an invented figure, perhaps loosely based on the Russian's last lover Nora Polonskaya) (Jangfeldt 442-46). It is not only a means of making Mayakovsky relevant, a force for action (as Fo does with Gramsci although with lesser necessity as he was a better known figure in Italy) but most significantly of demonstrating that revolutionary artists who bring their works to the 'people' can force a change in their consciousness and mould them into a social, cohesive force. There is therefore a dialectical relationship between Fo and Mayakovsky in which Fo infuses Mayakovsky with his ideas and Mayakovsky becomes the example of how a writer can achieve revolutionary status and relevance. Mayakovsky is rewritten to fit Fo's agenda even to the point that Fo occupies his poetics.

The construction of Mayakovsky as exemplar strengthens the perception that his example is intended to be practical - a demonstration of a didactic, pedagogical theatre. It is multi-faceted in that the poetic recitation is framed by a Mayakovskyan-style satire of the Stalinist bureaucracy. This first part presents a comic interaction between the workers and the police officers investigating Mayakovsky's suicide ("la farsa dei poliziotti") (Fo, Le commedie di Dario Fo, Vol. 3 100), perhaps a grotesque inversion of Gramsci's interaction with workers that opens the second act. The central scene between Mayakovsky's former lover Anna and the Stalinist cultural functionary centres on a discussion of the role of the dramatist and the theatre in the context of the Party. In fact the provocative role of the artist is underscored by Fo's insertion of the "pantomima" which, because it refers forward to the burning contemporary issues of the day, obviously cannot have been written by Mayakovsky. It does however confirm the cultural strategies of the Italian playwright: satire and farce as the cultural tools to fight the revolution 
despite the incomprehension of the Party. In all this there is nothing exceptional: our expectation would be that Fo legitimizes his role in this way. The example at this point appears straightforwardly programmatic but the 'appearance' onstage of Mayakovsky reading his poetry brings into play the "damage" or cost of the exemplary approach.

The recitation of the poem on the death of Lenin creates a rhetorical rupture, profoundly betraying Fo's poetics. Of the three parts that constitute the Mayakovsky episode, two, the comic-grotesque investigation into the poet's suicide and the satirical discussion of his relationship to the Party, can be considered an integral part of Fo's theatrical methodology and meet the expectations of his concept of farce. However the concluding section cannot: the choric recitation of a Mayakovsky poem reveals a serious turn, an attempt to underscore the political commitment of the author to revolutionary change through a dramatic, intense scenic action that excludes the comic. Such a move cannot simply be attributed to the crisis of the 'Hot Autumn' (Soriani 240) since L'operaio is bookended by Mistero buffo and the satire Morte accidentale di un anarchico. The effect of pathos, both here and in the earlier tragic account of Michele lu Lanzone, signals that in order to be effective the example must have recourse to rhetorical techniques that undermine the writer's poetics. The success of the example is paramount so the playwright is forced to abandon his own style and genre to enable revolutionary culture to be performed by the 'people' (with his help), requiring both didacticism and emotion. Fo prepares for the final example of Mayakovsky through Michele lu Lanzone: it is suggestive of the power of the emotions, and teaches how the peasants rebelled against the landowners in a Maoist form of revolution as an alternative to the Communist Party. The economy of tragedy or pathos is a hidden but necessary strategy for the working of the example.'

The example of Mayakovsky speaks to the contemporary Communist Party as a kind of plea to understand the potentiality of the writer as revolutionary. The poem on Lenin marks a crossroads: the historical inevitability of Stalin, or a Party that remains true to its origins. Thus the example of Gramsci implicitly recalls the foundation of the Italian Communist Party, and explicitly underlines the primordial importance of popular culture in conjunction with the concept of the organic intellectual. If it was Gramsci's Party, Mayakovsky's poem could

\footnotetext{
${ }^{9}$ Despite the fact that the stage direction to Michele lu Lanzone states that "la Madre" should act in a manner that is "sempre epica-mai naturalista" (Fo 1975, 109), this does not detract from the pathos that is implicated in the piece. It is not a Mutter Courage.
} 
still be recited. In fact, L'operaio marked Fo's definitive break with the PCI (he was no longer permitted to perform in case del popolo). In this context, the play evinces nostalgia for a Party that allows space for the creation of a poem like Lenin. Despite the anti-Communist Party sentiment of the play, the short extracts from the poem on Lenin surprisingly emphasize the unifying role of the party: "Il partito è una mano con milioni di dita" and "Il partito è nostro" (Fo, Le commedie di Dario Fo, Vol. 3 127). The final quotation from Lenin is a rebuke to the idea of compromise with capitalism; rather, it sees the role of the Party as its destroyer (Le commedie di Dario Fo, Vol. 3 128). It may be that Fo is confirmed in his role as jester because his manifesto is rejected by the Party, while the pathos-filled example of Mayakovsky is suggestive of the idea that tragedy is at the source of his comic inspiration.

\section{The example of Mayakovsky in Bene's Quattro modi}

In Quattro modi, Mayakovsky—through his poems and as a character himselfcomes to play an exemplary role at three different levels. At the level of practice, Mayakovsky's poems enable Bene to perform his vocal techniques in conjunction with voice manipulation and amplification, and in ways that are not explored in his Esenin, Blok and Pasternak. At an existential level, Mayakovsky as a character is an example of a possible path that brings together life and art, and provides a form of aesthetic and political resistance. At a conceptual level, it is Mayakovskythrough Bene's arrangement of his poems in a carefully constructed dialoguewho interprets and judges the others, in the context of a wider self-reflection that becomes a poetic rule, one that is both outlined and performed by Bene the actor. This, as we will see shortly, implies a merging of Mayakosvky the character and Bene himself.

The construction, stylisation and 'fiction' of Bene's Mayakovsky in the Quattro modi is coherent with the poetic argument outlined by Bene in this period, in particular with the botta e risposta with Gilles Deleuze around the 1977 production of Riccardo III (Bene and Deleuze). Two quotes from Bene's reply to Deleuze contribute, in rather explicit terms, to a poetics that fits with the Quattro modi.

'Grande attore è un quid al di là del concetto [...]: è quel niente che sa esprimere, Eliogabalo ingenuo e pervertito che sommerge di fiori dalle sue finestre un popolo affamato, per deconcettualizzare la fame' (Bene and Deleuze 120). The 
reference to Antonin Artaud's Heliogabalus, or the Crowned Anarchist, posits this 'quid beyond concept' as anarchist in nature. But anarchist here means also minor (in a Deleuzian sense), and emarginato, inattuale. On this, Bene directly echoes Deleuze:

non basta proporre una nuova rappresentazione del movimento, dacché la rappresentazione è già mediazione. Si tratta invece di produrre nell'opera un movimento capace di smuovere lo spirito al di fuori di ogni rappresentazione, e di fare dello stesso movimento un'opera che escluda l'interposizione, di sostituire dei segni diretti a rappresentazioni mediate, d'inventare vibrazioni, rotazioni, vortici, gravitazioni, danze o salti che tocchino direttamente lo spirito. (Bene and Deleuze 121).

At the conclusion of his reply, he adds: "[q]ueste giovani anime ${ }^{10}[\ldots]$ si rammaricano perché emarginate. [Ė] davvero l'autoemarginazione che hanno in dispregio, coincidendo questa posizione con la sola conquista [...] possibile, se 'possibile' è solo al di là della storia" (121).

Bene explicitly adopts the concept of auto-emarginazione to discuss the four Russian poets in the context of Quattro modi. In an interview with Vittorio Sermonti entirely devoted to the 1974 production, Bene states: "si emarginarono loro, non si lasciarono emarginare dagli eventi; e non cercarono di piazzare socialmente la loro libertà impossibile, la loro inattualità [...] Chi apprezza più oggi il lusso dell'auto-emarginazione?" (Sermonti 269). The umbrella under which this auto-emarginazione is played out is a io ipertrofico, a dilatazione dell'io, through which these "dandies of the revolution" fight the battle "con una storia che li sopraffaceva e, insieme, 'rappresentava' la loro irrappresentabilità, una controparte che li imbalsamava” (272).

In the light of the poetics outlined in Bene's reply to Deleuze this quote leads us to posit the four poets as exemplary; they embody historical actualisations of the poetic rules and, in this, their different political paths are reframed under the umbrella of radical individualism. However, in the context of this very poetics, any inductive/deductive dialectic, reference to or gesture towards conceptualisation and/or representation can appear only at the price of a contradiction and

\footnotetext{
${ }^{10}$ A reference to contemporary theatre people.
} 
incoherence with the practice that is professed. Logically speaking, Bene should perform his examples without imbalsamarli inside an explanation, and thus without imbalsamarsi in the process. Bene is called to practice emarginazione, instead of teaching it. In other words, he would need to avoid the explicit setting out of the rules and laws of a manifesto (Somigli). The option available to Bene is to see, perform and relate to Mayakovsky as a genius in the Kantian sense: an example to be followed without falling into the mediation of categorisation, or a judgement through aesthetic rules (Kant, Critique of Judgement $\$ 49 ; 117$ ). Alternatively, Bene would become a teacher, a pedagogue that 'explains' Mayakovsky, but always falling short of the ideal he is addressing (Lloyd 264-5). If the latter is the case, we would be able to find evidence of rhetorical strategies that construct, stylise/ fictionalise/idealise the examples as ideal representatives of a rule.

Quattro modi is divided in sections devoted to each poet. Superimposed titles introduce each of the poets but not the title of the poems. The texts become thus the lines of characters/poets played by Bene: a mimesis that merges the actor with his examples (Harvey, Labyrinths of Exemplarity: At the Limits of Deconstruction 25), while at the same time allowing a reading of each character as a particular position inside a dialogue that could just as well be internal to Bene himself. In this context, Bene/Blok, Bene/Esenin and Bene/Pasternak are interpreted in a relatively 'traditional' fashion. In Blok the awareness of the coming to an end of his pre-revolutionary world is stressed. Esenin is portrayed as the marginalised dandy, while Pasternak is invested (and we will soon discuss the importance of this) with a more reflective tone and role. It is with Mayakovsky, however, that the radical research on the nexus between voice, vocal techniques, voice manipulation and amplification comes into fruition. If the revolutionary tone is achieved through volume, pace, reverberation and a rather nasal emission (one of Bene's trade-marks) from the very beginning in Bene!, it is with La nuvola in calzoni, All'amato se stesso e Di questo that Bene's voice, while still 'reading' the text, seems at the same time to abandon it, abandoning himself to vocal virtuosities that become the prominent, and often the sole medium through which a meaning is conveyed to an overwhelmed audience. In the interview mentioned above, Bene himself confirms this preference, as for him "Mayakovsky si abbandonò all'innocenza del divenire, che è sempre però un divenire cosmico, un divenire che ritorna su di sé" (Sermonti 271). This self-centred abandonment to the innocence of becoming, which shortly after this interview will be fully articulated inside a theory of voice and subjectivity (Bene, La voce di Narciso), is what Bene 
puts into practice by 'becoming Mayakovsky' in the Quattro modi. This implies an exemplarity that is not argued or explained, but only shown: Bene/Mayakovsky is persuasive because of the affective power of his voice; his persuasion is, as per etymology, a 'seduction' that does not need to go through a conceptual mediation, one that is de-conceptualized.

The relationship between this performance and the text in which it takes place lays bare a degree of ambiguity. First of all, the fact that the vocal performance does not abandon the text, a text in which the io ipertrofico (Sermonti) of the poet reflects on art and existence, implies that we are not witnessing a quid al di là del concetto. The conceptual aspect is present, if only as a springboard for the performance. The audience witnesses a process (telos?) of de-conceptualisation, from language, through language, and finally away from it, thus only gesturing towards the quid beyond concepts, as the ultimate end-point. Bene will articulate this relationship in different ways throughout his life, and this ongoing articulation can be considered his major contribution to a theory of performance. For our argument, however, a more overt and problematic contradiction is central. The springboard for the performance is in fact a script, carefully planned along dramatic lines (with implicit or explicit intertextual references, questions and replies by different characters/poets, etc.), a script constructed out of a careful arrangement and strategic amendment of texts by the four poets. In this script, a rather explicit pedagogical conceptualisation seems to take centre stage. This pedagogical perlocutionary agenda revolves around the concept of art and artistic life as a necessary ruin-a declension of the prescriptive task of self-emargination-and develops through a carefully orchestrated dialogue between each poet's self-reflection. Inside this crafted dramaturgy, Mayakovsky is once again the protagonist. And he is so in the measure in which he plays the role of guide and interpreter, leading to the explicit articulation of a poetic of 'ruin.'

Two examples outline the spectrum of this practice, and lead us to a series of conclusions. The first occurs at the opening of the reading/play, when Bene reads Blok's Là dove echeggia nelle lunghe sale while a series of cross-cuts establish a dialogue with another, un-identified character, also played by Bene. This character sits ambiguously between 'Bene himself' and Bene/Mayakovsky, sharing the setting and the background (red, flames, fire) that will come to identify Mayakovsky throughout the play. The ambiguity has an immediate exemplary role: Blok talks to Bene and/as Mayakovsky, as if the two were sharing the same position (spatially, artistically, intellectually), with the arrangement of the texts 
making Blok a precursor of the aesthetics of the revolutionary others. His 'defeat' foreshadows the 'ruin' that will later be lived out by the others ('non raccattare quel fiore: v'è in esso / il dolce oblio di tutti i giorni andati / e tutta la frenetica allegria / della tua future rovina'), and articulated through Pasternak as the interpretive concept of the poetic life/art nexus. Juxtaposed to this opening are two excerpts of Mayakovsky's poem Bene!. Here Mayakovsky, spectator and target of Blok's exhortation, is the privileged interpreter of the poem: "E tutt' intorno affondava / la Russia di Blok... / [...] E subito il suo volto / divenne più sinistro / della morte invitata a nozze / [...]." Blok becomes a precursor of poetic ruin thanks to the interpretation provided by Mayakovsky: and Bene! is a title that once again playfully tightens the link between the actor and his character. ${ }^{11}$

The second example occurs in the section on Esenin, where Mayakovsky's role as an interpreter/teacher for/to the audience is further developed. Mayakovsky's In morte di Esenin follows here the performance of Esenin's poems, thus dramatically merging the chronologies of poetry and life in the moment of suicide. The poem allows Bene/Mayakovsky to bring to the fore the main themes of Bene's auto-emarginazione. Those who attempt an interpretation of the reasons behind suicide, who pretend to understand the emarginated artist, and with this lay bare their ideological rhetoric, are target of Mayakovsky's scorn. The section constructs a link between writing, artistic practice and its relationship with death, that is further addressed later in the play, acquiring a crucial role in the definition and, we ought to say, conceptualisation of Bene's poetic through the Russian poets: "Forse / ci fosse stato / inchiostro all'Angleterre / non avreste avuto ragione / di tagliarvi le vene." Esenin becomes the example used by Mayakovsky the 'teacher' to present a poetic through a stylisation. An example of existential marginalisation is reframed inside a specific relation with language and poetic writing, and inside a wider logic of political resistance. The fact that the latter, with the exception of the scorn for the political bureaucrats, is introduced in the play through praise of Esenin, allows Bene also to avoid discussing Mayakovsky's specific active involvement with the Revolution and the role of the Party. Outside the reply to Blok discussed above, in fact, this crucial aspect of Mayakovsky is effaced from the Quattro modi, or given a marginal, contextual relevance. Through the apology of Esenin, Bene creates a stylisation of both Esenin and, most crucially, Mayakovsky, which fits with

${ }^{11}$ In the poem, Mayakovsky describes his encounter with Blok, in which Blok's first words are 'Bene!.' In the play, this could mean 'well', as well as 'Carmelo Bene', further stressing his equivalence with Mayakovsky. 
his aims: "ma attenti: io Majakovskij lo rispetto sempre come 'blusa gialla': un Majakovskij bolscevico, non lo vedo"12 (Sermonti 270). Bene’s agenda, persona and politics further merge with the Russian.

These two examples show that in the Quattro modi, it is not only poetic language that provides a springboard to the 'non-conceptual' vocal performance, in its ambiguous residual presence, but rather a conceptual and conceptualising lecture, an argument about poetics. Mayakovsky/Bene is both genius and pedagogue, and the perlocutionary aim of the play works at both levels.

The model audience for both of the above positions is exemplified in the last section of the play by Pasternak. He witnesses Mayakovsky's vocal and poetic performance, followed by the close up of a gun pointed upwards, and a shot, in which the suicide becomes de-personalised, as if a slogan-like scream towards the sky. From this affective and yet concept-bound experience, Pasternak's two final poems are arranged and edited to articulate aesthetic and existential consequences, for himself and for the audience. The first, Morte d'un poeta, his famous tribute to Mayakovsky, contextualises the death and the shotgun, explaining its existential, artistic and political meaning: "il tuo sparo fu simile a un Etna / in un pianoro di vigliacchi e di vigliacche." The second comes with the abrupt introduction of nonoriginal, extra-diegetic music, and historical black and white footage of Pasternak's funeral procession. This is on one hand a further reiteration of self-reflection, and on the other a change of perspective, an estrangement that creates a space of reflection for the audience as well. The sequence follows Pasternak's dead body, and halts with a still frame on his face. Here, Bene's voice, now disembodied as if an explanatory voice-over, reads Oh sio avessi allora presagito. As much as the opening of the play was about Bene's 'reflection' in/as Blok and Mayakovsky, here Bene/Pasternak reflects on himself, once again reiterating the nexus between art and ruin. This time, rovina is presented in the most explicit, explanatory terms: "Oh, s'io avessi allora presagito / [...] che le righe con il sangue uccidono", and the "esigenza" of a "completa autentica rovina" becomes the lesson that Pasternak learns. Here, Bene meaningfully cuts the last stanza of the poem, leaving rovina as the last, reverberating word of the performance (Pasternak 237).

\footnotetext{
${ }^{12}$ Bene is referring here to Mayakovsky's early poem La blusa del bellimbusto (1914), a poem which would fit with the idea of a 'dandy of the revolution', and one which reference on voice would have resonated with Bene: "Mi cucirò calzoni neri / col velluto della mia voce / e una blusa gialla con tre metri di tramonto" (Majakovskij, Opere. Vol.1 28).
} 
Pasternak is thus a further mediator for the audience, modelling interpretation. But in doing this, he is in fact reiterating one of the two conflicting aspects of the character Mayakovsky. This is the contradiction. The agenda of Quattro modi is one of self-legitimisation not only by showing a practice, as it professes, but also by telling it, explaining it and arguing its case. It is, in many ways a manifesto, one that gestures towards an inductive/deductive dialectic that intrinsically betrays what it is sets out to perform; one that paradoxically aims at establishing and explaining the need to be marginalised and incomprehensible.

\section{Conclusions}

The theory of exemplarity that we have used has allowed us to map the complexities of these two works. Pointing out the insufficiency of the inductive/ deductive paradigm of exemplarity is thus an entry point into the implicit and yet constitutive perlocutionary economies that make these texts persuasive. In this sense, we are not saying that Fo and Bene are simply incoherent, but rather that in order to convincingly profess a poetic, they have to say (or hide) much more. Our two authors reimagine Mayakovsky in rather different ways: Bene sees him as an individualist anarchist, and Fo as a disillusioned party intellectual. In doing this, Fo and Bene stylise his life and works to merge with an idealised version of their own, thus providing the tools for each of them to assert himself in a new and not necessarily welcoming context. The texts become in this sense a manifesto, immediately political and aesthetic.

In introducing exemplarity, however, there is a necessary betrayal. In Fo, this betrayal is of farce in favour of tragedy and pathos; in Bene, it is the constitutive presence of a conceptual and rational element as a springboard for the lyric. Paradoxically, this brings two very different aesthetics (and politics) closer to each other. Despite what is explicitly professed, both texts share an investment in a third person, self-reflective conceptualisation, as well as in the persuasive power of poetry.

Having demonstrated that L'operaio and Quattro modi are poetic manifestos for Fo and Bene respectively opens further questions and areas of inquiry. The question here is if and to what extent other texts and performances written and conceived under this poetic umbrella partake with the ambiguities we outlined in this contribution. Fo's experiment with performances in case del popolo was short lived so that the question of the extent to which the theatre manifesto of L'operaio 
is pertinent to his later work requires further investigation. Are the pathos and tragic tonalities of L'operaio still active in the later farcical work of Fo or are they to be solely associated with his ill-fated attempt as a dissident intellectual to critique the Communist Party? And, in the case of Bene, is the conceptualising subtext of the Quattro modi a singular example dictated by the contingencies of this production, or is this a more widespread trait of his theatre? In other words: can we support a critique of Bene as 'allegorical' (Artioli and Bene), one that finds an undermining didacticism as a conditio sine qua non for his vocal and performance techniques?

Our comparative study of Fo and Bene using exemplarity as the focus allowed us to pinpoint the ambiguities within a single text, thus problematizing a specific and symbolic moment in the career of the two artists. However, we believe that this provides an opening to a broader inquiry into their developing poetics.

The University of Melbourne

\section{Works Cited}

Artaud, Antonin. Heliogabalus, or the Crowned Anarchist. Washington: Solar Books, 2007.

Artioli, Umberto and Carmelo Bene. Un dio assente. Monologo a due voci sul teatro. Milan: Medusa, 2006.

Bene, Carmelo. "La ricerca teatrale nella rappresentazione di Stato." La Ricerca impossibile. Biennale Teatro '89. Venice: Marsilio, 1990. 11-17. . La Voce Di Narciso. Milan: Il Saggiatore, 1982.

Bene, Carmelo and Gilles Deleuze. Sovrapposizioni. Macerata: Quodlibet, 2002.

Colombo, Enzo, and Orlando Piraccini, eds. Pupazzi con rabbia e sentimento. Lla vita e l'arte di Dario Fo e Franca Rame. Milan: Scheiwiller, 1998.

D'Arcens, Louise. Comic Medievalism: Laughing at the Middle Ages. Cambridge: D. S. Brewer, 2014.

De Man, Paul. The Rhetoric of Romanticism. New York: Columbia University Press, 1984.

Deleuze, Gilles, and Felix Guattari. 1000 Plateaus: Capitalism and Schizophrenia. London: Continuum, 2004. 
Ebert, Teresa L. "Manifesto as Theory and Theory as Material Force: Toward a Red Polemic.” JAC 23.3 (2003): 553-562.

Farrell, Joseph. Dario e Franca. La biografia della coppia Fo-Rame attraverso la storia italiana. Milan: LEdizioni, 2014.

Fo, Dario. Le Commedie Di Dario Fo. Vol. 3. Turin: Einaudi, 1975.

. Teatro politico di Dario Fo. Compagni senza censura. Vol 1. Milan: Mazzotta, 1977.

Gelley, Alexander. "Introduction." Unruly Examples. On the Rhetoric of Exemplarity. Ed. Alexander Gelley. Stanford, California: Stanford University Press, 1995. 1-24.

Giacchè, Piergiorgio. Carmelo Bene: Antropologia di una macchina attoriale. Milan: Bompiani, 2007.

Harvey, Irene. Labyrinths of Exemplarity: At the Limits of Deconstruction. New York: SUNY Press, 2002.

Jangfeldt, Bent. "Mayakovsky. A Biography." 2014: n. pag.

Kant, Immanuel. Critique of Judgement. Mineola, New York: Dover Publications, 2005.

Critique of Pure Reason. Cambridge: Cambridge University Press, 1998.

Lloyd, David. "Kant's Examples." Unruly Examples. On the Rhetoric of Exemplarity. Stanford: Stanford University Press, 1995. 255-276.

Lyons, John D. Exemplum. The Rhetoric of Example in Early Modern France and Italy. Princeton, NJ: Princeton University Press, 1989.

Majakovskij, Vladimir. Messaggi ai posteri selezionati e condivisi da Dario Fo. Ed. Anna Benedettini. Rome: Editori Riuniti, 1994. . Opere. Vol. 1. Rome: Editori Riuniti, 1958.

Mitchell, Tony. Dario Fo. People's Court Jester. London: Methuen, 1999.

Pasternak, Boris. Poesie. Turin: Einaudi, 2001.

Petrini, Armando. Amleto da Shakespeare a Laforgue per Carmelo Bene. Pisa: ETS, 2004.

Porter, Robert. "From Clichés to Slogans: Towards a Deleuze-Guattarian Critique of Ideology." Social Semiotics 20.3 (2010): 233-245.

Puchner, Martin. Poetry of the Revolution: Marx, Manifestos and the Avant-Gardes. Princeton, NJ: Princeton University Press, 2006.

Scuola di Barbiana. Lettera a una professoressa. Florence: Libreria Editrice Fiorentina, 1967. 
Sermonti, Vittorio. “Il manifesto di Carmelo Bene." Panta 30 (2012): 269-273.

Somigli, Luca. Legitimizing the Artist: Manifesto Writing and European Modernism. Toronto: University of Toronto Press, 2003.

Soriani, Simone. Dario Fo: Dalla commedia al monologo (1959-1969). Pisa: Titivillus, 2007.

Suleiman, Susan Rubin. Authoritarian Fictions: The Ideological Novel as a Literary Genre. Princeton: Princeton University Press, 1983. 